\title{
Cerebral abnormalities in infants with myelomeningocele
}

\section{Nieprawidłowości mózgu u niemowląt z przepuklinq oponowo-rdzeniowq}

\author{
George A. Alexiou', Maria K. Zarifi', George Georgoulis', Eleni Mpouza33, Christiana Prodromou', Athina Moutafi', Marina Anagnostakou³, \\ George Sfakianos', Neofytos Prodromou'
}

'Department of Neurosurgery, Children's Hospital 'Agia Sofia', Athens, Greece

2Department of Radiology, Children's Hospital 'Agia Sofia', Athens, Greece

${ }^{3} 2^{\text {nd }}$ Department of Neonatology, Children's Hospital 'Agia Sofia', Athens, Greece

Neurologia i Neurochirurgia Polska 2011; 45, 1: 18-23

\begin{abstract}
Background and purpose: We evaluated brain abnormalities associated with myelomeningocele in infants.

Material and methods: Between June 1995 and June 2008, 42 patients with myelomeningocele were treated in our hospital. Only 24 patients (13 males, 11 females, mean age 1.5 months, range 1 day -11 months) were evaluated by both spinal and brain magnetic resonance imaging (MRI) and were enrolled in the study.

Results: Brain MRI revealed: hydrocephalus in 21 (87.5\%) patients, all of whom required immediate shunting. Total agenesis of the corpus callosum was observed in $2(8.3 \%)$ patients, partial agenesis was seen in $4(17 \%)$ patients and $8(34 \%)$ patients had dysplasia of the corpus callosum. Absence of the septum pellucidum was observed in $2(8 \%)$ patients. Widening of the interhemispheric fissure and colpocephaly were noted in $10(41 \%)$ and in $3(12 \%)$ patients, respectively. Abnormal white matter maturation was observed in $2(8 \%)$ patients. Small posterior fossa was observed in $18(74 \%)$ patients, Chiari malformation in $16(67 \%)$ patients, cerebellar and brain stem hypoplasia in 3 (12\%) and 7 (30\%) patients, respectively.

Conclusions: MRI examination of the myelomeningocele site is not sufficient. Clinicians should consider obtaining imaging studies of the entire neuraxis in patients with myelomeningocele.
\end{abstract}

Key words: spinal dysraphism, myelomeningocele, MRI, brain.

\section{Streszczenie}

Wstęp i cel pracy: W pracy oceniono występowanie nieprawidłowości mózgu u niemowląt z przepukliną oponowo-rdzeniową.

Materiał i metody: Od czerwca 1995 r. do czerwca 2008 r. w naszym ośrodku leczono 42 pacjentów. Do badania włączono 24 chorych (13 chłopców i 11 dziewczynek; średni wiek 1,5 miesiąca; zakres wieku: od 1 dnia do 11 miesięcy), u których wykonano badanie mózgu i rdzenia kręgowego za pomocą rezonansu magnetycznego (RM).

Wyniki: Rezonans magnetyczny mózgu wykazał obecność wodogłowia u 21 pacjentów $(87,5 \%$ ) (wszyscy wymagali niezwłocznego wszczepienia drenażu komorowego). Brak ciała modzelowatego stwierdzono u 2 (8,3\%), częściowe niewykształcenie ciała modzelowatego u 4 (17\%), a dysplazję ciała modzelowatego u 8 pacjentów (34\%). Brak przegrody przezroczystej obserwowano u 2 (8\%), poszerzenie szczeliny międzypółkulowej u 10 (41\%), a kolpocefalię u 3 pacjentów (12\%). Nieprawidłowe dojrzewanie istoty białej dotyczyło 2 pacjentów (8\%). U 18 osób (74\%) stwierdzano małą objętość tylnego dołu czaszkowego, u 16 (67\%) malformację Arnolda-Chiariego, a odpowiednio u 3 (12\%) i 7 (30\%) hipoplazję móżdżku i pnia mózgu.

Wnioski: Badanie RM samej przepukliny oponowo-rdzeniowej nie jest wystarczające. Klinicyści powinni rozważyć wykonanie badań obrazowych całej osi nerwowej u chorych na przepuklinę oponowo-rdzeniową.

Słowa kluczowe: wady rdzenia kręgowego z grupy dysrafii, przepuklina oponowo-rdzeniowa, rezonans magnetyczny, mózg.

Correspondence address: George Alexiou, MD, Aetideon 52, Holargos, Attikis, 11561, Greece, phone: $+302106526507,+306948525134$, e-mail: alexiougrg@yahoo.gr

Received: 22.06.2010; accepted: 11.10.2010 


\section{Introduction}

Spinal dysraphism encompasses a heterogeneous group of congenital spinal anomalies that result from defective closure of the neural tube [1]. Tortori-Donati et al. proposed a simple classification of spinal dysraphism based on clinical and MRI findings [2]. Although the closed form of spinal dysraphism may be asymptomatic, the open form is usually associated with several disabilities. Myelomeningocele is the most common type of open spinal dysraphism and results from failed closure of the caudal end of the neural tube during the fourth week of gestation, in which there is a protrusion of a portion of the spinal cord through a midline bony defect of the spine, forming an open lesion or sac containing cerebrospinal fluid and dysplastic neural tissue [3]. The vast majority of myelomeningoceles are sacral or lumbosacral in location. However, thoracic and cervical myelomeningoceles exist $[1,2]$.

There has been a significant decrease in the number of infants born with myelomeningocele, because of improved maternal nutrition and wider availability of prenatal diagnostic tests, namely maternal serum alphafetoprotein screening and real-time ultrasonography [4]. Closure of this abnormality should be performed in the early postnatal period, whereas approximately 330 cases of intrauterine repair have been performed in specialized centres worldwide $[1,4,5]$. Depending on the location of the defect, considerable neurological deficits occur. Patients usually suffer from lower limb paralysis and sensory loss, bladder and bowel dysfunction [1].

Myelomeningocele has also been associated with multiple cerebral defects that are directly related to intellectual and cognitive function [6-8]. Hydrocephalus has been suggested as the main cause of any cognitive dysfunction [9-11]. Furthermore, Vinck et al. suggested that several cognitive deficits may be attributed apart from hydrocephalus to Arnold-Chiari malformation [12]. Regarding cerebral findings in patients with myelomeningoceles, the majority of studies evaluated patients of all age groups. In the present study we evaluated cerebral abnormalities accompanying myelomeningocele in children under one year of age.

\section{Material and methods}

From June 1995 to June 2008, 42 patients with myelomeningocele were treated in 'Agia Sofia' Chil- dren's Hospital. All patients underwent imaging studies of the entire neuraxis within a week from presentation. Among them, 24 patients were evaluated by both spinal and brain magnetic resonance imaging (MRI) and were enrolled in the study. The remaining patients were excluded from the study because they were evaluated by brain computed tomography.

There were 13 males and 11 females (mean age 1.5 months at MRI study, range: 1 day -11 months). The spinal lesions were located in the lumbar region in 22 patients and in the sacral region in 2 patients. Brain and spinal MRI was performed with a 1.0 T Siemens, Harmony MRI scanner. All patients had T1-weighted $(\mathrm{Tr}=500 \mathrm{~ms}, \mathrm{Te}=8.9 \mathrm{~ms})$ and $\mathrm{T} 2$-weighted $(\mathrm{Tr}=$ $4000 \mathrm{~ms}, \mathrm{Te}=105 \mathrm{~ms}$ ) examinations in axial, sagittal and coronal planes. All examinations were evaluated by two independent experienced paediatric radiologists (one of whom was a paediatric neuroradiologist); any possible disagreements were resolved by consensus.

\section{Neuroimaging diagnostic criteria}

Chiari I malformation was defined as inferior displacement of the cerebellar tonsils $5 \mathrm{~mm}$ or greater below the foramen magnum. Chiari II malformation was defined as displacement of the brainstem and lower cerebellum into the cervical spinal canal and the presence of a small posterior fossa. Cerebellar hypoplasia was diagnosed when one or both cerebellar hemispheres were small with short but normally arranged fissures. Brain stem hypoplasia was diagnosed when the brainstem had reduced sagittal dimensions and the anterior curvature of the pons was flattened. Small posterior fossa was diagnosed when the posterior fossa had reduced sagittal dimensions with a corresponding steeply inclined tentorium. Regarding definition of white matter maturation, on T1-weighted images the intensity of white matter relative to grey matter increased with maturation and on $\mathrm{T} 2$-weighted images maturation was interpreted as reduction in intensity of white relative to grey matter. Partial agenesis of the corpus callosum was defined as absence of a part of the corpus callosum. Hypoplasia of the corpus callosum was defined as thin corpus callosum.

\section{Results}

The cerebral abnormalities associated with meningomyelocele are summarized in Table 1. 
Table 1. Magnetic resonance imaging findings of the 24 patients

\begin{tabular}{|lcc|}
\hline & No. & $\%$ \\
\hline Supratentorial & 21 & 87.5 \\
\hline Lateral ventricular dilatation & & \\
\hline Corpus callosum & 2 & 8.3 \\
\hline Total agenesis & 4 & 17 \\
\hline Partial agenesis & 8 & 33 \\
\hline Dysplasia & 10 & 41 \\
\hline Wide interhemispheric fissure & 2 & 8 \\
\hline Missing septum pellucidum & 3 & 12 \\
\hline Colpocephaly & 4 & 16 \\
\hline Enlargement of subarachnoid spaces & 2 & 8 \\
\hline Heterotopic grey matter (periventricular) & 2 & 8 \\
\hline Immature white matter & 1 & 4 \\
\hline Polymicrogyria & 3 & 12.5 \\
\hline Infratentorial & 18 & 74 \\
\hline Small posterior fossa & 16 & 67 \\
\hline Chiari malformation & 3 & 12.5 \\
\hline Chiari malformation I & 13 & 54.6 \\
\hline Chiari malformation II & 30 \\
\hline Hypoplasia of cerebellum & & \\
\hline Hypoplasia of brainstem & & \\
\hline Cervical syringe - hydromyelia & & \\
\hline
\end{tabular}

\section{Supratentorial abnormalities}

Hydrocephalus was an almost constant finding and was found in $21(87.5 \%)$ patients. The occipital horns were dilated more than the frontal and temporal horns in $4(16 \%)$ of the patients. Children presenting with hydrocephalus required immediate shunting. A cyst near the third ventricle and multiple small cysts on either side of the interhemispheric fissure were observed in $2(8 \%)$ patients, respectively. Enlargement of subarachnoid spaces was observed in $4(16 \%)$ patients. Total agenesis of the corpus callosum was observed in $2(8.3 \%)$ patients, both of whom had colpocephaly. Partial agenesis of the corpus callosum was seen in 4 (17\%) patients, 1 of whom also had polymicrogyria, and hypoplasia of the corpus callosum was observed in $8(33 \%)$ patients. Absence of the septum pellucidum was observed in $2(8 \%)$ patients. Another common finding was the presence of a wide interhemispheric fis- sure that was observed in 10 (41\%) patients. Six of them also had corpus callosum abnormalities. Colpocephaly was observed in $3(12 \%)$ patients. Abnormal white matter maturation was observed in $2(8 \%)$ patients and heterotopic grey matter was also observed in 2 other (8\%) patients.

\section{Infratentorial abnormalities}

A small posterior fossa was observed in $18(74 \%)$ patients. Chiari type II was observed in 13 (54.6\%) patients, whereas, interestingly, $3(12.5 \%)$ patients had Chiari I malformation. In 2 cases of Chiari II malformation, a cervicomedullary kink was also noted. All patients with Chiari II were symptomatic and were treated surgically. A suboccipital craniectomy and C1 laminectomy with or without duroplasty was performed. Hypoplasia of the cerebellum was observed in 3 (12\%) patients, whereas hypoplasia of the brain stem (mainly pontine hypoplasia) was observed in 7 (30\%) patients. Cervical syrinx was found in 1 patient.

\section{Discussion}

Myelomeningocele has been associated with multiple cerebral defects that have been based mostly on autopsy studies. By means of MRI only a few studies have evaluated patients of all age groups with myelomeningocele [6-8]. In the present study, after evaluation of the cerebral abnormalities in children under one year of age, we found a spectrum of accompanying disorders.

Hydrocephalus is a common finding in patients with myelomeningocele, usually appears 2-3 days after surgery and requires a shunt placement. Talamonti et al. reported that $78 \%$ in a series of 220 patients with myelomeningocele were treated for hydrocephalus [13]. Furthermore, Just et al. in a series of 44 patients with myelomeningocele reported that hydrocephalus was observed in 27 patients [6]. The size of the lateral ventricles may vary; symmetric and asymmetric dilatation can be observed [6]. In our series, the occipital horns were dilated more than the frontal and temporal horns in 4 patients, a finding that has been noted in congenital hydrocephalus from other aetiologies as well. Furthermore, colpocephaly was noted in $12 \%$ of our patients.

Anomalies of neuronal migration that usually cause seizures and variable developmental retardation have 

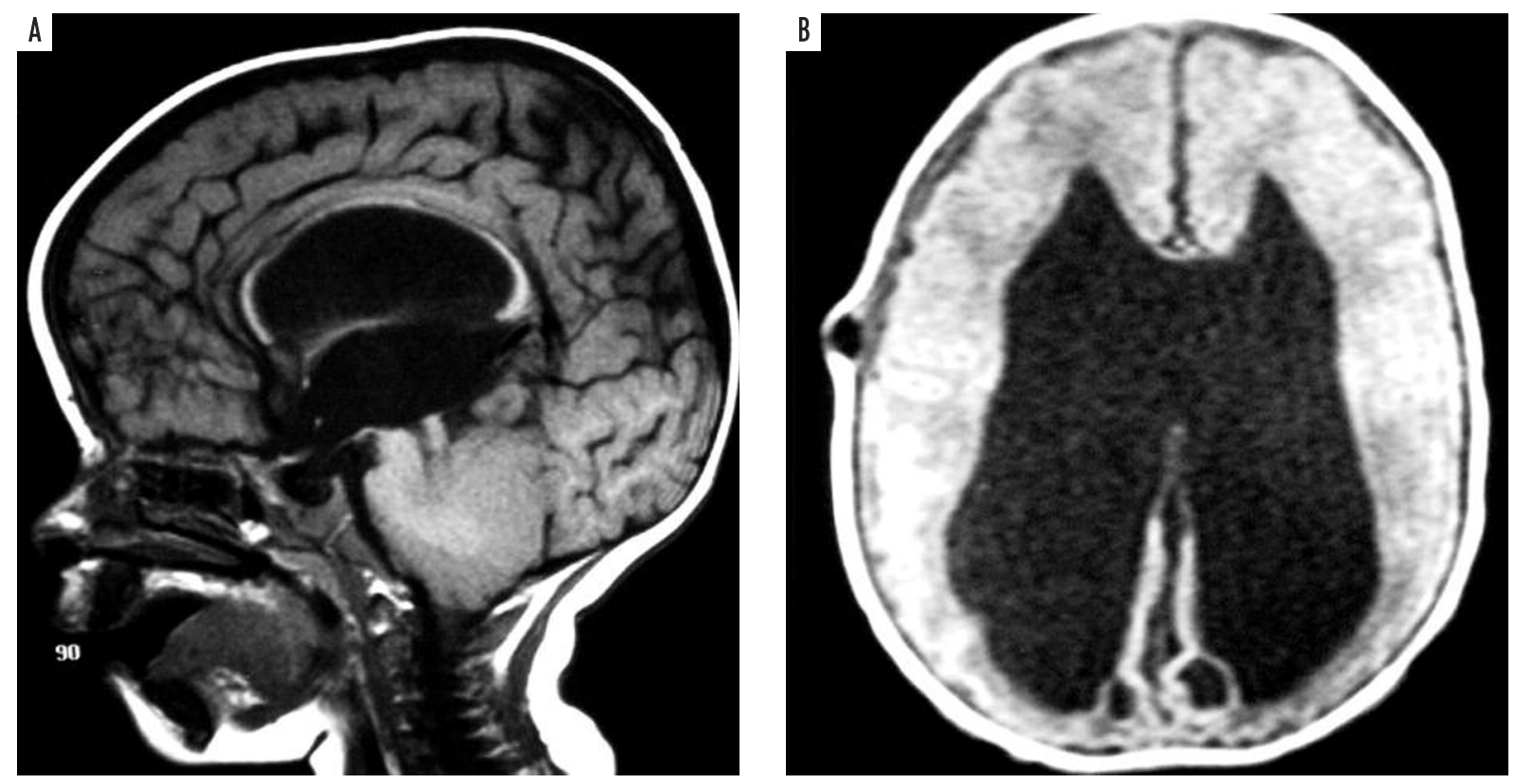

Fig. 1. A) Sagittal MRI of an 11-day-old boy demonstrating thin corpus callosum, Chiari malformation type II and hydrocephalus. B) Axial MRI of a 3-month-old girl revealing absence of the septum pellucidum, hydrocephalus and small cysts near the occipital horns

been reported in association with myelomeningocele $[14,15]$. In an autopsy study, Gilbert et al. noted cerebral heterotopias in $92 \%$ of children who died with myelomeningocele [15]. Just et al. described this malformation in 6 out of 44 patients [6]. In our study, small nodules of heterotopic grey matter along the occipital horns were observed in 2 patients. Furthermore, in 2 patients features of abnormal white matter maturation were seen. Hasan $e t$ al. recently studied white matter microstructural abnormalities in children with myelomeningocele by means of diffusion tensor tractography and reported abnormal white matter development and persistent degeneration with increased age relative to control patients [8]. Juranek et al. also studied the total cerebral volumes, neocortical surface area, and neocortical thickness in children with myelomeningocele and found a significant $15 \%$ reduction in total white matter and a $69 \%$ increase in cerebrospinal fluid, with no differences in total grey matter relative to the control group [16]. Additionally, there was a significantly smaller neocortical surface area in the occipital regions [16].

Total or partial agenesis of the corpus callosum is a common finding in patients with myelomeningocele. Just $e t$ al. reported a frequency of $56 \%$ of partial agenesis of the corpus callosum and Kawamura et al. observed partial agenesis of the corpus callosum in 50\% of patients [6,7]. Polymicrogyria, a cause of epileptogenesis and mental retardation, has been observed in
$33 \%$ of patients with myelomeningocele $[7,17]$. In our study, polymicrogyria was observed in 1 patient. Absence of the septum pellucidum is a frequently reported abnormality in patients with myelomeningoceles that usually occur with abnormalities of the corpus callosum [6, 18-20]. In our study, there were 2 patients with absence of the septum pellucidum, 1 of whom had partial agenesis of the corpus callosum.

Concerning infratentorial abnormalities, the best known and best documented in patients with myelomeningocele is Chiari malformation type II. Just et al. found Chiari malformation in $76 \%$ of patients [6]. In our series, we observed Chiari malformation in $67 \%$ of our patients. The presentation of symptomatic Chiari may vary depending on the child's age. Worley et al. reported that $23 \%$ of children with spina bifida were symptomatic from Chiari II malformation at some point but only $17 \%$ required hindbrain decompression [21]. Nevertheless, decompression should be performed early for symptomatic Chiari II in order to promote a prompt and full neurological recovery $[22,23]$. Likewise, in our study all patients with Chiari II malformation were symptomatic and operated on. Interestingly, 3 patients showed features of Chiari I malformation. This type of Chiari malformation is an unusual finding in patients with myelomeningocele, but it has been described in cases of closed spinal dysraphism [24]. 

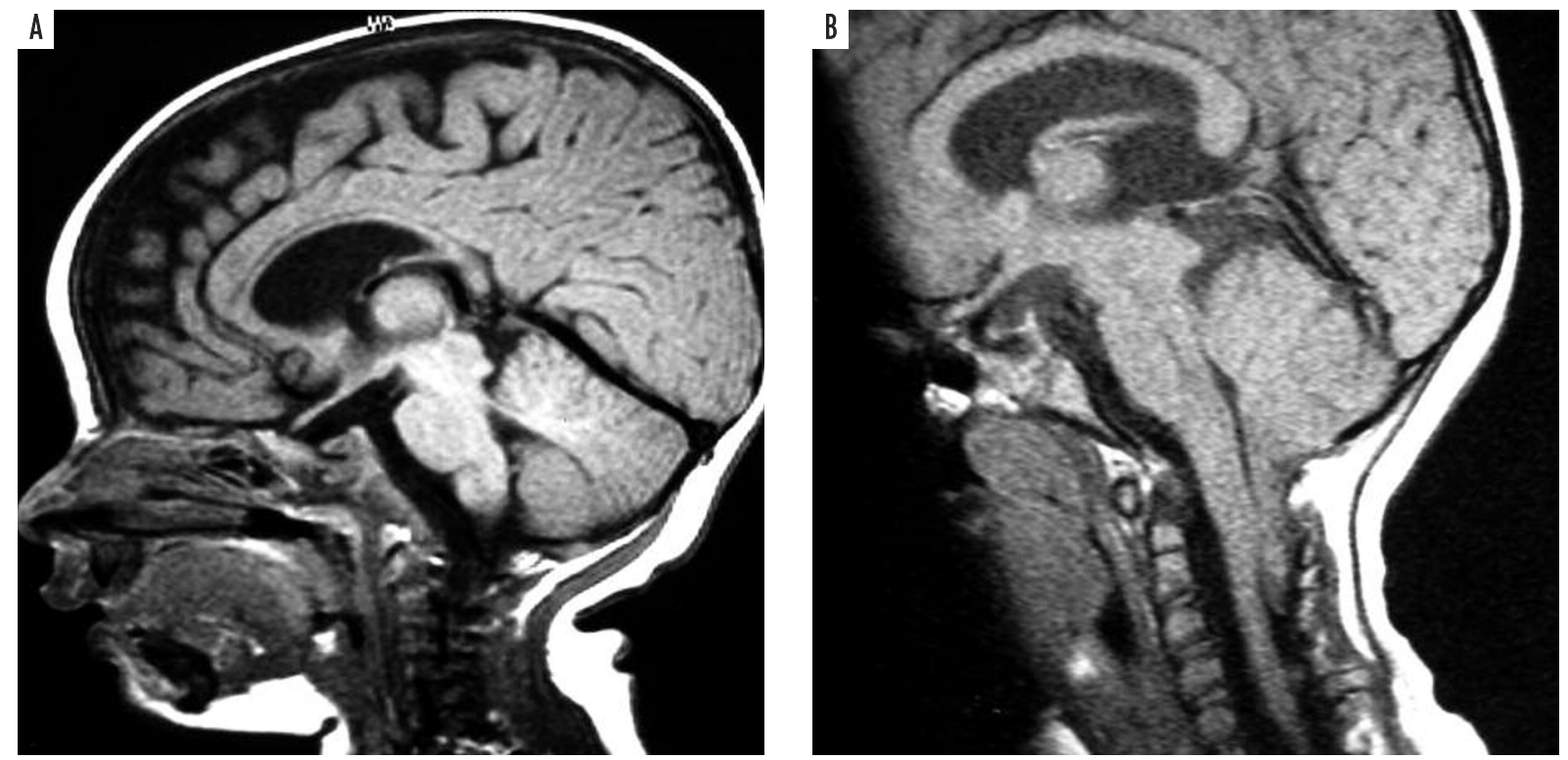

Fig. 2. A) A 1-day-old girl with thin corpus callosum. B) Sagittal MRI of a 2-month-old girl showing Chiari malformation type II, brainstem hypoplasia and cystic enlargement of the third ventricle

In $74 \%$ of our patients a small posterior fossa was present. Another common finding was brain stem and cerebellar hypoplasia, which can result in the patient's neurological deterioration. Cervical syrinx was also observed in 1 patient. Just et al. reported that syrinx occurred in all sections of the spinal cord and the size varied from small circumscribed cavities to considerable lesions extending to the total length of the cord [6]. Caldarelli et al. observed the presence of syrinx in 32/142 patients with spina bifida and concluded that the incidence of syrinx is actually higher than that reported in the literature but not all lesions are symptomatic [25]. Therefore, close follow-up is mandatory for patients at risk for neurological deterioration.

Apart from MRI, computed tomography and ultrasonography have been used as alternative imaging techniques $[18,19,26]$. Nevertheless, computed tomography has the disadvantage of radiation exposure and ultrasonography has a limitation in the evaluation of the posterior fossa, lower resolution and operator dependence. Furthermore, ultrasonography is limited to patients with open sutures and fontanelles. MRI is the imaging procedure of choice with the advantages of absence of ionizing radiation, and the capacity to produce images in planes with any orientation, providing excellent visualization of the brain and spinal cord [27].

Our study has several potential limitations. First, we did not perform volumetric measurements that would provide a more accurate characterization of our findings. Second, this study focused on the structural findings of brain MRI and did not address the predicted and actual long-term functional outcomes. Furthermore, we excluded patients with other types of spinal dysraphism. Investigation of the spinal and brain findings in these cases would be very interesting. This is the purpose of an ongoing study in our institute.

\section{Conclusions}

1. Brain imaging studies in these patients at an early age are of great importance.

2. Furthermore, the detection of possible structural brain abnormalities that are associated with neurocognitive development may provide clues to predict patient prognosis.

\section{References}

1. McComb J.G. Spinal and cranial neural tube defects. Semin Pediatr Neurol 1997; 4: 156-166.

2. Tortori-Donati P., Rossi A., Cama A. Spinal dysraphism: a review of neuroradiological features with embryological correlations and proposal for a new classification. Neuroradiology 2000; 42: 471-491.

3. Barkovich J. Pediatric Neuroimaging. 4th ed. Lippincott Williams \& Wilkins, Philadelphia 2005. 
4. Bruner J.P., Tulipan N., Paschall R.L., et al. Fetal surgery for myelomeningocele and the incidence of shunt-dependent hydrocephalus. JAMA 1999; 282: 1819-1825.

5. Fichter M.A., Dornseifer U., Henke J., et al. Fetal spina bifida repair - current trends and prospects of intrauterine neurosurgery. Fetal Diagn Ther 2008; 23: 271-286.

6. Just M., Schwarz M., Ludwig B., et al. Cerebral and spinal MR-findings in patients with postrepair myelomeningocele. Pediatr Radiol 1990; 20: 262-266.

7. Kawamura T., Morioka T., Nishio S., et al. Cerebral abnormalities in lumbosacral neural tube closure defect: MR imaging evaluation. Childs Nerv Syst 2001; 17: 405-410.

8. Hasan K.M., Eluvathingal T.J., Kramer L.A. White matter microstructural abnormalities in children with spina bifida myelomeningocele and hydrocephalus: a diffusion tensor tractography study of the association pathways.J Magn Reson Imaging 2008; 27: 700-709.

9. Dise L.E., Lohr M.E. Examination of deficits in conceptual reasoning abilities associated with spina bifida. Am J Phys Med Rehabil 1998; 77: 247-251.

10. Snow J.H., Prince M., Souheaver G., et al. Neuropsychological patterns of adolescents and young adults with spina bifida. Arch Clin Neuropsychol 1994; 9: 277-287.

11. Iddon J.L., Morgan D.J., Loveday C., et al. Neuropsychological profile of young adults with spina bifida with or with out hydrocephalus. J Neurol Neurosurg Psychiatry 2004; 75: 1112-1118.

12. Vinck A., Maassen B., Mullaart R., et al. Arnold-Chiari-II malformation and cognitive functioning in spina bifida. $J$ Neurol Neurosurg Psychiatry 2006; 77: 1083-1086.

13. Talamonti G., D’Aliberti G., Collice M. Myelomeningocele: long-term neurosurgical treatment and follow-up in 202 patients. J Neurosurg 2007; 107: 368-386.

14. Barkovich A.J., Chuang S.H., Norman D. MR of neuronal migration. AJNR 1987; 8: 1009-1017.

15. Gilbert J.N., Jones K.L., Rorke L.B., et al. Central nervous system anomalies associated with meningomyelocele, hydrocephalus, and the Arnold-Chiari malformation: reappraisal of theories regarding the pathogenesis of posterior neural tube closure defects. Neurosurgery 1986; 18: 559-564.

16. Juranek J., Fletcher J.M., Hasan K.M., et al. Neocortical reorganization in spina bifida. Neuroimage 2008; 40: 1516-1522.

17. Chassoux F., Landre E., Rodrigo S., et al. Intralesional recordings and epileptogenic zone in focal polymicrogyria. Epilepsia 2008; 49: 51-64.

18. Babcock D.S., Han B.K. Caffey award: cranial sonographic findings in meningomyelocele. AJR Am J Roentgenol 1982; 136: 563-569.

19. Zimmerman R.D., Breckbill D., Dennis M.W., et al. Cranial CT findings in patients with meningomyelocele. AJR Am J Roentgenol 1979; 132: 623-629.

20. Miller E., Widjaja E., Blaser S., et al. The old and the new: supratentorial MR findings in Chiari II malformation. Childs Nerv Syst 2008; 24: 563-575.

21. Worley G., Schuster J.M., Oakes W.J. Survival at 5 years of a cohort of newborn infants with myelomeningocele. Dev Med Child Neurol 1996; 38: 816-822.
22. Pollack I.F., Kinnunen D., Albright A.L. The effect of early craniocervical decompression on functional outcome in neonates and young infants with myelodysplasia and symptomatic Chiari II malformations: results from a prospective series. Neurosurgery 1996; 38: 703-710.

23. Vandertop W.P., Asai A., Hoffman H.J. Surgical decompression for symptomatic Chiari II malformation in neonates with myelomeningocele. J Neurosurg 1992; 77: 541-544.

24. Genitori L., Peretta P., Nurisso C., et al. Chiari type I anomalies in children and adolescents: minimally invasive management in a series of 53 cases. Childs Nerv Syst 2000; 16: 707-718.

25. Caldarelli M., Di Rocco C., La Marca F. Treatment of hydromyelia in spina bifida. Surg Neurol 1998; 50: 411-420.

26. Byrd S.E., Radkowski M.A. The radiological evaluation of the child with a myelomeningocele. J Natl Med Assoc 1991; 83: 608-614.

27. Gilman S. Imaging the brain. First of two parts. $N$ Engl J Med 1998; 338: 812-820. 